\title{
Pesquisas, enquetes e estudos eleitorais
}

Flavio Eduardo Silveira ${ }^{1}$

A análise do que se costuma usualmente chamar de pesquisa eleitoral requer, preliminarmente, definições conceptuais. $\mathrm{O}$ termo pesquisa abrange um conjunto de diferentes significados. Chamamos de pesquisa o trabalho dos meios acadêmicos, produzido com base em consistente fundamentação teórica e metodológica e desenvolvido, em períodos relativamente longos, através de cuidadoso processo de aplicação de procedimentos técnicos. Quando comparamos os preços de um mesmo produto em três ou quatro lojas situadas em locais próximos falamos que pesquisamos antes de efetuar a compra. Alunos costumam dizer que fizeram uma "pesquisa na Internet", quando retiraram informações de alguns sites visitados. O apresentador de um programa de televisão utiliza o termo pesquisa para se referir a algumas poucas e rápidas entrevistas feitas com pessoas que estavam se deslocando nas ruas. Há muita diferença entre estas formas de colher informações chamadas inadequadamente pela mesma palavra.

Uma tentativa recorrente de diferenciação dos tipos de pesquisa refere-se à inclusão do termo "científico" para distinguir um trabalho metodologicamente orientado de outras formas espontâneas de colher informações. Embora o termo não seja o mais apropriado - considerando os objetivos deste artigo, não será analisado o problema da cientificidade, da noção leiga sobre o "científico" como forma de diferenciar o verdadeiro do falso e de autorizar ou de legitimar discursos -, esta diferenciação é suficiente para distinguir a investigação metodologicamente controlada de outros levantamentos empíricos produzidos sem a

\footnotetext{
${ }^{1}$ Doutor em Sociologia pela USP, coordenador do Programa de Pós-Graduação em Ciências Sociais da Pucrs e diretor da Meta Instituto de Pesquisa.
} 
observação de critérios técnicos adequados. Esta diferenciação é freqüientemente empregada no campo eleitoral para distinguir a pesquisa "científica" das enquetes feitas por emissoras de rádio e de TV a partir da manifestação espontânea dos eleitores ou estimulada por meio de inquirição, através de contato pessoal, de telefone ou da Internet. A principal objeção a estas enquetes não se refere ao número de entrevistados, pois em alguns casos os volumes são grandes, mas à falta de critérios para a composição da amostra. Quando o critério para a inclusão na amostra é a iniciativa do ouvinte ou telespectador, a probabilidade de distorção é muito grande. Dificilmente uma amostra composta desta forma apresentaria as mesmas características de uma amostra selecionada e distribuída a partir de critérios estatísticos.

Para ser representativa a amostra deve conter as principais características da população investigada. De acordo com a teoria probabilística, podem ser utilizados critérios para a estratificação da amostra (isto é, divisão do universo populacional em estratos, segundo os critérios considerados mais relevantes) e deve ser realizado um sorteio aleatório dos elementos de cada estrato, fornecendo a cada elemento igual chance de ser sorteado. De acordo com o sistema de amostragem por cotas, a seleção dos entrevistados é feita na mesma proporção das principais características da população. Geralmente são consideradas as características sexo, idade, escolaridade e renda. A enquete que seleciona os entrevistados a partir da intenção dos repórteres ou do acaso, assim como aquela feita a partir da manifestação espontânea da população, tende a superdimensionar a participação de alguns segmentos e sub-dimensionar a participação de outros (às vezes participam em maior proporção as mulheres, ou os mais idosos, ou os mais escolarizados, ou os mais indignados, e assim por diante).

O termo "científico", contudo, é insuficiente para distinguir pesquisas de naturezas diferentes mas igualmente feitas com base em critérios estatísticos e procedimentos metodológicos adequados. No âmbito das pesquisas eleitorais, grosso modo podem ser discriminados dois tipos principais: as pesquisas produzidas por institutos de pesquisa, vinculados a órgãos privados ou públicos, que em geral têm objetivos mais imediatos relativos ao acompanhamento da disputa eleitoral, e as pesquisas realizadas nos meios acadêmicos, que têm objetivos a médio e longo prazos, relacionados com o conhecimento comportamental sobre os eleitores e agentes envolvidos no processo eleitoral. Nas pesquisas acadêmicas, em geral, há grande preocupação com as questões de caráter teórico. Os pesquisadores buscam produzir explicações fundamentadas dos fenômenos estudados, com base em uma reflexão mediata dos dados empíricos.

As pesquisas produzidas pelos institutos são orientadas, geralmente, por dois objetivos principais. O primeiro refere-se à produção de informações 
sobre a situação da competição eleitoral, visando à divulgação de dados nos meios de comunicação. Geralmente são divulgados dados sobre a intenção de voto dos eleitores (menção espontânea e induzida) para o primeiro e segundo turnos das eleições, sobre o grau de rejeição aos candidatos e sobre a avaliação do desempenho dos governos. Outro tipo de pesquisa eleitoral muito utilizada refere-se aos levantamentos não divulgados, realizados para os partidos e candidatos com o objetivo de coletar subsídios para o estabelecimento de estratégias de campanha. Estas pesquisas abrangem geralmente um conjunto mais amplo de questões, além dos indicadores de intenção de voto e rejeição, referente à imagem dos candidatos, aos pontos vulneráveis dos adversários, às percepções da população sobre aspectos relevantes da disputa eleitoral, sobre a correção e adequação das propostas e das condutas dos candidatos e sobre os fatos simbólicos mais influentes.

Estes dois tipos de pesquisa eleitoral, o primeiro produzido pelos institutos e o segundo, desenvolvido no meio acadêmico, encontram-se, em várias situações, amalgamados. Primeiramente porque não é incomum a utilização de dados de Institutos na produção de teses acadêmicas (Lavareda, 1991; Silveira, 1998). Em segundo lugar, porque há importante grupo de pesquisadores que se encontra nos "dois lados do balcão": fazem a pesquisa acadêmica e a pesquisa voltada para a campanha de partidos/candidatos em processos eleitorais. Um tipo de atividade, que tem um objetivo mais imediato e específico, possibilita uma experiência e o levantamento de dados relevantes para o outro tipo de atividade, a pesquisa acadêmica voltada à produção mediata de explicações sobre o comportamento dos partidos/candidatos e dos eleitores. Um bom exemplo da reunião de profissionais que apresentam este perfil pode ser encontrado no livro Marketing político e persuasão eleitoral, organizado por Rubens Figueiredo (2000). Em terceiro lugar, existem centros de pesquisa que reúnem os dois tipos de atividade, como é o caso, por exemplo, do Datauff, órgão vinculado à Universidade Federal Fluminense, que faz pesquisas eleitorais (como se fosse um instituto de pesquisa), pesquisas acadêmicas e treinamento de alunos em metodologia e em pesquisa. Por sua vez, o Centro de Estudos de Opinião Pública (CESOP), da Unicamp, reúne bancos de dados das pesquisas feitas pelos principais institutos brasileiros, disponibilizando estes dados para as pesquisas acadêmicas.

Embora trabalhos acadêmicos utilizem dados das pesquisas produzidas pelos Institutos e ainda que, por vezes, os mesmos profissionais atuem nestas duas áreas, existem, de qualquer modo, características que distinguem os dois tipos de pesquisa mencionados. Os objetivos da pesquisa acadêmica são mediatos e estão direcionados à construção de explicações mais abrangentes do processo eleitoral. São estudos realizados em longos períodos de tempo e geralmente são fundamentados em reflexões teóricas. Os objetivos das pesquisas 
eleitorais produzidas pelos institutos são mais imediatos e estão relacionados especificamente à campanha eleitoral; seus resultados são utilizados instrumentalmente para divulgar a situação da competição na mídia e para orientar as estratégias e táticas de campanha.

$\mathrm{Na}$ tradição intelectual dos Estados Unidos foram utilizados alguns termos específicos para designar os diferentes tipos de pesquisa. O termo research tem o sentido amplo que o termo pesquisa apresenta no Brasil. Significa pesquisa, busca, indagação e investigação de qualquer natureza. Mas o termo específico survey é utilizado com um sentido técnico para designar exame, levantamento e laudo. Este termo passou a ser empregado pelos institutos de pesquisa e na área acadêmica para designar a pesquisa quantitativa de opinião política feita com base em critérios estatísticos e procedimentos metodológicos adequados. As características deste tipo de pesquisa foram descritas pelo excelente trabalho Métodos de pesquisa de survey de Earl Babbie (1999). Segundo o autor, os trabalhos de Marx sobre a situação dos trabalhadores assalariados na França no final do século XIX e de Weber sobre a ética protestante no início do século $\mathrm{XX}$ envolveram, de forma precursora, métodos da pesquisa de survey. As pesquisas destes pensadores da sociologia clássica em muito se diferenciam dos atuais trabalhos caracterizados pelo mesmo termo. Os levantamentos destes intelectuais envolviam a aplicação de questionários, mas não as técnicas estatísticas de amostragem. A chamada "enquete operária" de Marx foi feita a partir do envio pelo correio de 25.000 questionários aos trabalhadores franceses, mas não se sabe ao certo quantos foram respondidos. Os trabalhos de pesquisa feitos com base em técnicas de amostragem foram desenvolvidos posteriormente, a partir das décadas de 1930 e 1940, nos Estados Unidos, por empresas comerciais de pesquisa de opinião (George Gallup, Elmo Roper, Louis Harris, entre outras) e na área acadêmica, com a utilização de métodos mais sofisticados de análise (Samuel Stouffer, Paul Lazarsfeld, entre outros). O termo survey foi sendo crescentemente utilizado para diferenciar o levantamento de dados cuidadoso e tecnicamente adequado de outras pesquisas chamadas nos Estados Unidos de poll, relativas à opinião pública, ao questionamento sobre determinados temas junto à população, aos testes de opinião pública. O termo poll tem um significado similar ao termo enquete (do francês enquête), que significa inquirição, investigação, pesquisa, informação. Outro motivo relevante para a utilização do termo survey se refere à necessária distinção entre a pesquisa de natureza política de outros levantamentos feitos pelos institutos sobre as opiniões e preferências dos consumidores sobre produtos, empresas e marcas. Tais levantamentos são caracterizados como pesquisa de mercado (market research) no sentido de uma pesquisa que é realizada no mercado de consumidores sobre o mercado de produtos e seus agentes, ou pesquisa de marketing (marketing research), no sentido de pesquisa sobre o processo de conquista do consumidor 
para a venda de produtos. O termo pesquisa de marketing é utilizado por vários autores da área da administração e da publicidade para designar um tipo específico de pesquisa direcionada ao processo que associa consumidor e empresa (Malhotra 2001).

As distinções entre um levantamento cuidadoso do ponto de vista técnico e metodológico, de um lado, de outras formas de colher opiniões da população, de outro, e entre pesquisa de opinião política e eleitoral, de um lado, e pesquisa de mercado, de outro, são apropriados, mas não são suficientes para resolver o problema aqui proposto. Buscando maior precisão conceptual, para efeito da análise que será desenvolvida, é necessário distinguir levantamentos de informação feitos sem maiores cuidados técnicos daqueles produzidos pelos institutos de pesquisa e das pesquisas produzidas pela área acadêmica. Considerando esta necessidade, discriminamos a seguir as características diferenciais dos três tipos principais de pesquisa de natureza política e eleitoral.

Chamamos de enquete todo o tipo de coleta de informações feita sem a observação de critérios metodológicos e técnicos adequados. Estamos nos referindo às entrevistas feitas pelos meios de comunicação e outros levantamentos que nos fornecem uma idéia sobre o assunto de interesse, que pode ser um pouco ou muito imprecisa. Para designar este tipo de coleta de informação também é recorrentemente utilizado o termo sondagem. Contudo, este último não é o termo mais apropriado, pois sua origem (sonda, do francês sonde, derivado do anglo-saxão sund, que significa mar) refere-se a um cuidadoso trabalho tecnicamente controlado de exploração de um meio (inicialmente água e posteriormente solo e ar) através de aparelhos (sondas) que permitem captar informações. A sondagem da água é feita através de instrumento para se conhecer a altura da água ou a natureza do fundo. A sondagem do solo refere-se à perfuração de um terreno para a verificação de sua natureza geológica, de lençóis de água, de jazidas. A sondagem do ar refere-se às observações feitas por meio de um teodolito e de balões de borracha repletos de oxigênio para conhecer a circulação dos ventos nas altas camadas da atmosfera. Os trabalhos de sondagem requerem aparelhos especializados e trabalho técnico controlado, sendo, portanto, distintos de levantamentos de opinião produzidos de maneira tecnicamente duvidosa. O termo enquete é mais apropriado para designar a reunião de testemunhos sobre determinado assunto, geralmente feita por uma emissora de rádio ou de televisão.

Os termos pesquisa eleitoral serão utilizados no sentido estrito, tendo como referência a experiência dos institutos de pesquisa. Estamos nos referindo a um tipo de levantamento de dados, produzidos a partir de critérios metodológicos e rigor técnico, tendo em vista os objetivos imediatos de conhecer elementos de um processo eleitoral em curso, seja para divulgar um retrato do quadro eleito- 
ral em um dado momento, seja para produzir subsídios úteis à ação política. O tipo mais comum de pesquisa eleitoral é a pesquisa de intenção de voto, divulgada pela mídia. Mas o termo pesquisa eleitoral também abrange metodologias qualitativas, como as técnicas das entrevistas em profundidade, dos grupos focais e dos grupos de discussão. Enquanto os levantamentos quantitativos fornecem a representação estatística das tendências gerais de opinião do conjunto da população investigada, as pesquisas qualitativas tornam possível o conhecimento em profundidade de dimensões subjetivas das percepções de pequenos grupos de eleitores, selecionados de acordo com perfis determinados. Pesquisas quantitativas e qualitativas são produzidas pelos institutos tendo em vista à aplicabilidade imediata dos resultados em um processo eleitoral. Este objetivo condiciona o tipo de trabalho realizado, que deve atender à demanda de rapidez própria da disputa eleitoral.

As pesquisas produzidas pelos institutos diferenciam-se dos trabalhos desenvolvidos na área acadêmica, que serão chamados de estudos eleitorais. $\mathrm{O}$ termo estudos neste caso é mais apropriado pois o trabalho acadêmico é mais abrangente que uma pesquisa. Estudo pode envolver dados de mais de uma pesquisa, como é o caso dos estudos longitudinais que acompanham as mudanças comportamentais em períodos relativamente longos. Estudo pode abranger dados empíricos de uma pesquisa, seja ela de natureza quantitativa ou qualitativa, assim como, dados de outras fontes, trabalhados pelo pesquisador. Estudo é um termo mais adequado para dar conta da dimensão processual de construção do conhecimento acadêmico. Estudo supõe uma preocupação especial com os problemas teóricos, metodológicos e epistemológicos. Isto é, uma preocupação especial com o problema do olhar do pesquisador. O conhecimento do comportamento eleitoral que buscam os estudos acadêmicos não se restringe a um processo eleitoral específico e à aplicabilidade instrumental. O trabalho acadêmico está preocupado em produzir reflexões de alcance teórico. A aplicabilidade do conhecimento acadêmico refere-se às explicações, de caráter geral, do comportamento do eleitorado, dos condicionamentos do voto e do sistema político. Os estudos acadêmicos podem utilizar dados de pesquisas eleitorais, mas buscam trabalhar estes dados em um quadro teórico mais amplo.

Neste artigo serão abordadas as modalidades de coleta de dados mais relevantes para a problemática eleitoral: a tradição acadêmica de estudo eleitorais e a experiência dos institutos de produção de pesquisas eleitorais.

\section{A experiência acadêmica no Brasil}

É relativamente recente a produção de estudos eleitorais abrangentes, teoricamente fundamentados, construídos a partir de pesquisa empírica relevante. Até o final dos anos 1940 os ensaios produzidos sobre o assunto apresentavam 
reflexões gerais, baseadas em observações, impressões e pressupostos ideológicos, e fracamente apoiadas em dados empíricos.

Nestes primeiros estudos que abordaram, de algum modo, a questão do voto, predomina a visão do eleitorado como massa politicamente amorfa e manipulável: o eleitorado inculto que vota sem consciência política e ideológica (Amaral 1938; Vianna 1951); o eleitorado que vota em função da relação de subordinação ao "coronel" local (Leal 1949); o eleitorado, prisioneiro da política clientelista, que troca seu voto por benefícios pessoais imediatos, que vota em função da identidade com lideranças políticas personalistas e que não se reconhece nos partidos, organizações artificiais dominadas pelo personalismo e carentes de coerência e de representatividade social (Jaguaribe 1950; Carvalho 1957). Nos termos desta representação intelectual do eleitorado não há porque explicar a decisão do voto. As explicações construídas voltam-se às condições que limitam a possibilidade de decisão do voto (clientelismo/mundo rural), às quais são contrapostas condições idealizadas que supostamente possibilitariam uma escolha eleitoral consciente definida por princípios ideológicos (cidadania/mundo urbano).

Nas décadas de 1950 e 1960 ampliou-se o volume de estudos eleitorais na área acadêmica. Foram desenvolvidas análises sobre o comportamento do eleitorado tendo por base os dados oficiais da Justiça Eleitoral. Aziz Simão, em $O$ voto operário em São Paulo (1956), analisou a relação entre posição sócioeconômica e voto nas eleições de 1945 e 1947. O autor demonstrou, a partir da distribuição dos resultados eleitorais por região da capital paulista, a existência de forte correlação entre a posição sócio-econômica do trabalhador assalariado fabril e a opção de voto predominantemente orientada para os partidos politicamente vinculados às causas operárias e trabalhistas.

Nos primeiros estudos eleitorais propriamente ditos, publicados no início dos anos 1960 na Revista Brasileira de Estudos Políticos e no livro Comportamento eleitoral no Brasil organizado por Cavalcanti e Dubnic (1964), as análises do eleitorado e das disputas eleitorais são preliminares e relativamente superficiais. De um modo geral, os exames dos processos eleitorais estão voltados aos temas da escolha dos candidatos, da motivação dos candidatos para o pleito, da descrição dos acontecimentos da campanha eleitoral, das características da propaganda eleitoral, da situação dos partidos em consequiência do pleito, da renovação das Assembléias, da idade dos eleitos, da sua situação econômica e do seu nível intelectual. As poucas menções ao eleitorado referem-se ao número de pessoas que compareceram às urnas e aos resultados oficiais do pleito. Nestes estudos sobre o "comportamento eleitoral", o eleitor é o grande ausente. Eles descrevem alguns aspectos da campanha eleitoral, mas não explicam as razões de um ou outro comportamento do eleitorado. As tentativas de 
explicação recorrem ao modelo anteriormente mencionado. A análise de Júlio Barbosa sobre as eleições de 1962 em Minas Gerais, por exemplo, apontou o predomínio de "motivações do tipo tradicional e particulares" ao invés de motivações "ideológicas". Reconhecendo os limites dos trabalhos da época, Oliveiros Ferreira (1964) afirmou que "ainda está por fazer-se, no Brasil, um estudo sério e sistemático da arregimentação do voto".

Uma nova tradição de estudos eleitorais surgiu na década de 1970 com trabalhos analíticos de maior fôlego, entre os quais destacam-se três coletâneas: Os partidos e as eleições no Brasil, organizada por Bolivar Lamounier e Fernando Henrique Cardoso, analisou os resultados das eleições de 1974 em São Paulo, Minas Gerais e Rio Grande do Sul; Os partidos e o regime: a lógica do processo eleitoral brasileiro, organizada por Fábio Wanderley Reis, reuniu ensaios elaborados a partir dos dados de surveys padronizados realizados em 1976 em quatro cidades de porte médio (Presidente Prudente-SP, Niterói-RJ, Juiz de Fora-MG e Caxias do Sul-RS), e Voto de desconfiança: eleições e mudanças políticas no Brasil 1970-1979, organizada por Bolivar Lamounier, analisou as eleições de 1978 em São Paulo e procurou fazer um balanço do período.

A maior parte dos estudos examinou, a partir de suveys, o perfil do eleitorado, a diferenciação sócio-econômica, etária e sexual do voto, a geografia do voto nas cidades, a preferência partidária, as percepções políticas-ideológicas do eleitorado (opiniões sobre temas da campanha e temas do debate político institucional) o grau de estruturação ideológica do eleitorado (consistência lógica entre as percepções político-ideológicas), e o significado das eleições. Refutando a tese do amorfismo e da inconsistência política do eleitorado, os autores mostram a diferenciação sócio-econômica das bases partidárias e sua distribuição geográfica (os bairros mais pobres eram os mais emedebistas) que, em linhas gerais, correspondem às percepções do eleitorado do MDB como partido dos "pobres", do "povo" e da Arena como partido dos "ricos", do "poder". A identificação partidária foi considerada elemento-chave para a explicação do comportamento eleitoral . No caso de uma cultura política como a do Rio Grande do Sul, a tradição partidária foi valorizada como elemento explicativo na medida que a antiga polarização das forças anti-PTB x PTB haviam se mantido no regime militar na forma Arena x MDB (Trindade 1974). O crescimento eleitoral do MDB a partir de 1974 é visto, de um modo geral, como produto da crescente identificação do eleitorado popular e jovem com o MDB como partido do "povo", comprometido com a mudança social.

Alguns estudos investigaram o universo simbólico de grupos do eleitorado, utilizando, ao invés de surveys, entrevistas abertas com um pequeno número de pessoas. Verena Martinez-Alier e Armando Boito Júnior (1975) buscaram, 
através do estudo Enxada e voto, a inteligibilidade do discurso de trabalhadores volantes de uma pequena cidade da região agrícola de Campinas (SP), através da reconstituição de sua memória política, de sua experiência e de sua visão de mundo. O trabalho Para que serve o voto? de Tereza Caldeira (1980) retratou como as eleições de 1978 foram vividas no cotidiano dos moradores do pauperizado e periférico bairro de São Miguel, da zona leste de São Paulo, assinalando as ambigüidades que marcaram esta vivência: a convivência do desinteresse e da vontade de participação, do ceticismo em relação ao processo eleitoral e da opção de participar dele, da descrença nos políticos e na política e da esperança de mudanças, da desconfiança em relação aos políticos e do voto no MDB, da desinformação política e do conhecimento de aspectos importantes dos mecanismos de funcionamento do sistema político.

Os trabalhos desta nova tradição representaram uma contribuição considerável à produção intelectual sobre comportamento eleitoral no Brasil. Contudo, pode-se identificar limitações importantes no que respeita à espinhosa e problemática tarefa de explicação do voto. As conclusões dos estudos situaram-se em um plano um tanto vago e impreciso. As explicações construídas, baseadas em elementos como diferenciação sócio-econômica e identificação partidária, não conseguiram ultrapassar o nível constatativo e morfológico (o crescimento eleitoral do MDB foi apresentado como produto da identificação dos setores populares com a oposição) e incursionar no terreno da explicação da decisão eleitoral.

Algumas das limitações acima apontadas foram reconhecidas pelos autores destas obras. Bolivar Lamounier (1975) afirmou que "o caráter diferencial, ao nível sócio-econômico, do comportamento eleitoral e das afiliações partidárias não exaure o problema de explicar a magnitude da votação oposicionista em São Paulo". Fábio Wanderley Reis (1978), na conclusão do livro Os partidos e o regime: a lógica do processo eleitoral brasileiro preferiu utilizar o título mais modesto Em busca da lógica do processo eleitoral brasileiro e recorreu, para construir sua reflexão sobre o assunto, aos modelos explicativos da "centralidade" e da "consciência de classe". Lamounier, por sua vez, buscou explicar o comportamento eleitoral em São Paulo a partir da combinação do modelo "clientelismo x ideologia" e do modelo da sociologia política americana que distingue partidarismo, personalismo e questões substantivas, associando o primeiro às expectativas o segundo aos objetos de identificação do eleitorado.

Os estudos sobre comportamento eleitoral no Brasil, após a rica "safra" da produção dos anos 70, reduziram-se consideravelmente na década seguinte. Mesmo assim, alguns trabalhos produzidos no período constituíram-se em relevante referência para o conhecimento sobre comportamento eleitoral. Entre 
eles deve-se mencionar o estudo de Eli Diniz (1982) sobre o "chaguismo", grupo articulado pelo deputado Chagas Freitas do MDB do Rio de Janeiro, que utilizava a máquina partidária e relações clientelistas para manter e ampliar o seu poder. Também tornou-se importante referência o estudo qualitativo de Flavio Pierucci (1987) sobre as referências valorativas e simbólicas antiigualitárias, autoritárias, chauvinistas, anti-nordestinas e moralizantes, orientadoras do comportamento de setores que constituíam "as bases da nova direita" janista e malufista de São Paulo. Uma interessante tentativa de explicação do comportamento do eleitor foi desenvolvida por Baquero (1984), que retomou as referências do paradigma de Converse para a análise do processo eleitoral de 1982 em Porto Alegre. O Idesp aglutinou pesquisadores relevantes e constituiu-se, nos anos 80, num centro de produção de pesquisas sobre opinião política e de estudos sobre os partidos e os processos eleitorais. Inscreveram-se nesta tradição os trabalhos de Maria D'Alva Kinzo (1988) sobre oposição e autoritarismo, Maria Tereza Sadek (1989) sobre as eleições de 1986 e de Bolivar Lamounier (1990) sobre a transição de Geisel a Collor.

Nos anos 1990 houve um importante revigoramento dos estudos acadêmicos sobre comportamento eleitoral. Ocorreram processos simultâneos enriquecedores, combinando o considerável crescimento do volume de estudos produzidos e a diversificação dos tipos de trabalho, com a ampliação de tradições intelectuais utilizadas para analisar os fenômenos partidários, políticos e eleitorais por diferentes ângulos e olhares. Foram elaborados trabalhos consistentes do ponto de vista teórico e fortemente amparados em dados empíricos. Nas tradições da Ciência Política e da Sociologia Eleitoral foram produzidos estudos que trabalharam modelos gerais de explicação do comportamento eleitoral. O trabalho de Marcus Figueiredo (1991) A decisão do voto: democracia e racionalidade construiu uma reflexão teórica sobre a decisão eleitoral com base na teoria da escolha racional. O estudo de Flavio Silveira (1998) sobre decisão do voto no Brasil, analisou o comportamento do eleitorado que decide por meio de intuição, sensibilidade e juízo de gosto, utilizando as imagens captadas da mídia sobre os candidatos e os fatos simbólicos relevantes da disputa eleitoral. José Álvaro Moisés (1995) desenvolveu uma tese geral sobre a democracia como valor fundamental no processo político eleitoral brasileiro e André Singer (2000) analisou o comportamento do eleitorado brasileiro, tendo por referência as percepções sobre as posições esquerda e direita.

No campo da Ciência Política e da Sociologia Eleitoral também foram produzidos neste período estudos relevantes: sobre os partidos políticos e o processo eleitoral brasileiro - A democracia nas urnas, Antônio Lavareda (1991) e Partidos e governos no Brasil contemporâneo, de Rachel Meneguelo (1998) -; sobre a transição política e o comportamento eleitoral - Depois da transição: democracia e eleições no governo Collor, de Bolivar Lamounier (1991) e 
Transição, eleições e opinião pública, de Marcelo Baquero (1995) -; e sobre políticos conservadores e suas bases eleitorais - A liderança política de Jânio Quadros, de Vera Chaia (1992) e São Paulo, 1992: a vitória da direita, de Flavio Pierucci (1993).

Outra importante contribuição aos estudos eleitorais nos anos 90 foi a iniciativa de pesquisadores analisarem o processo político e eleitoral sob a perspectiva da tradição antropológica. Ocorreu a valorização de aspectos desconsiderados pela tradição da Ciência Política e da Sociologia eleitoral relativos aos enredos, rituais e às vivências das campanhas eleitorais. Inscreveram-se nesta experiência os trabalhos de Moacir Palmeira e Irlys Barreira (1998) Candidatos e candidaturas: enredos de campanha eleitoral, Irlys Barreira (1998) Chuva de papéis: ritos e símbolos de campanhas eleitorais no Brasil, Nara Magalhães (1998) O povo sabe votar: uma visão antropológica e de Karina Kuschnir (2000) Eleições e representação no Rio de Janeiro.

Uma terceira tradição, igualmente relevante e que merece ser destacada entre os estudos eleitorais do período, refere-se aos trabalhos produzidos pelos pesquisadores da área de comunicação e política. A revista Comunicação \& Política divulgou, a partir de 1994, volume considerável de importantes artigos sobre a mídia, os cenários e os atores dos processos eleitorais. Nesta tradição destacaram-se os estudos de Venício de Lima (1994) Televisão e poder: a hipótese do "cenário de representação política", de Antônio Albino Rubim (1999) Mídia e política no Brasil, de Mauro Porto (1994) As eleições municipais em São Paulo, Afonso de Albuquerque (1995) Política versus televisão: o horário gratuito na campanha presidencial de 1994 e o trabalho organizado por Heloiza Matos (1994) Mídia, eleições e democracia. A partir de 1997 ocorreu a confluência dos pesquisadores da área de comunicação e política com os pesquisadores da área de Ciência Política e Sociologia Eleitoral interessados em estudar o fenômeno da mídia e seus impactos nos processos eleitorais, com a reunião destas duas tradições no Grupo de Trabalho da Anpocs, que anteriormente abordara temas sobre partidos políticos e comportamento eleitoral, e passou a incorporar o problema da mídia como elementos explicativo chave do voto. Resultaram desta confluência os trabalhos de Marcus Figueiredo, Alessandra Aldé, Heloísa Dias e Vladimyr Jorge (2000) Estratégias de persuasão em eleições majoritárias: uma proposta metodológica para o estudo da propaganda eleitoral, de Vera Chaia (2000) Mídia e política e os livros organizados por Antônio Albino Rubim (2000) Mídia e eleições 98 e por Flavio Silveira (2002) Estratégia, mídia e voto.

Por fim, devemos mencionar uma quarta tradição que nos anos 90 nos brindou com excelentes trabalhos sobre outro aspecto fundamental dos processos eleitorais contemporâneos: o marketing político. Entre outros, constituíram-se 
em importantes referências sobre o assunto os estudos sobre marketing político e comportamento eleitoral produzidos por Rubens Figueiredo e Mauro Malin A conquista do voto (1994), O que é marketing político? (1994), Marketing político e persuasão eleitoral (2000) e por Rodolfo Grandi, Alexandre Marins e Eduardo Falcão (1992) Voto é marketing... o resto é política.

Iremos apresentar, no quadro a seguir, uma breve e não exaustiva relação de estudos dos períodos referidos.

\begin{tabular}{|c|c|c|}
\hline Período & Principais autores & Principais obras \\
\hline Até 1950 & $\begin{array}{l}\text { Azevedo Amaral } \\
\text { Victor Nunes Leal } \\
\text { Hélio Jaguaribe } \\
\text { Oliveira Vianna } \\
\end{array}$ & $\begin{array}{l}\text { O Estado autoritário e a realidade nacional (1938) } \\
\text { Coronelismo, enxada e voto (1949) } \\
\text { Política de clientela e política ideológica (1950) } \\
\text { Instituições políticas brasileiras (1951) }\end{array}$ \\
\hline $1951-1970$ & $\begin{array}{l}\text { Aziz Simão } \\
\text { Vários } \\
\text { Fay Azevedo } \\
\text { Orlando de Carvalho } \\
\text { Cavalcanti e Dubnic } \\
\text { Oliveiros Ferreira } \\
\text { Gláucio Soares } \\
\text { Xausa e Ferraz } \\
\text { Octávio Cintra }\end{array}$ & $\begin{array}{l}\text { O voto operário em São Paulo (1956) } \\
\text { Revista Brasileira de Estudos Políticos (a partir de } \\
\text { 1957) } \\
\text { Os partidos políticos no Rio Grande do Sul (1957) } \\
\text { Ensaios de sociologia eleitoral (1958) } \\
\text { Comportamento eleitoral no Brasil (1964) } \\
\text { O comportamento eleitoral em São Paulo (1964) } \\
\text { Alianças e coligações eleitorais (1964) } \\
\text { Bases ideológicas do lacerdismo (1965) } \\
\text { As eleições de 1966 no Rio Grande do Sul (1967) } \\
\text { Partidos políticos em Belo Horizonte (1968) }\end{array}$ \\
\hline $1971-1980$ & $\begin{array}{l}\text { Gláucio Soares } \\
\text { Bolivar Lamounier e } \\
\text { Fernando H. Cardoso } \\
\text { Bolivar Lamounier } \\
\text { Vilmar Faria } \\
\text { Fábio Wanderley Reis } \\
\text { Olavo Brasil Lima Jr. } \\
\text { Hélgio Trindade } \\
\text { Hélgio Trindade e J. de } \\
\text { Cew }\end{array}$ & $\begin{array}{l}\text { Sociedade e política no Brasil (1973) } \\
\text { Os Partidos e as eleições no Brasil (1975) } \\
\text { Comportamento eleitoral em São Paulo: passado e } \\
\text { presente (1975) } \\
\text { Presidente Prudente: o crescimento da oposição num } \\
\text { reduto arenista (1978) } \\
\text { O voto de desconfiança (1980) } \\
\text { O voto em São Paulo, 1970-1979 (1980) } \\
\text { As eleições de 1974 no Estado de São Paulo: uma } \\
\text { análise das variações inter-regionais (1975) } \\
\text { As eleições em Minas Gerais (1975) } \\
\text { Os Partidos e o Regime: a lógica do processo eleitoral } \\
\text { brasileiro (1978) } \\
\text { Classe Social e Opção Partidária: as eleições de 1976 } \\
\text { em Juiz de Fora (1978) } \\
\text { Articulação de interesses, posição sócio-econômica e } \\
\text { ideologia: as eleições de 1976 em Niterói (1978) } \\
\text { Os padrões de comportamento eleitoral no Rio Grande } \\
\text { do Sul (1950/74) (1974) } \\
\text { Anatomia do voto em Porto Alegre (1975) } \\
\text { Padrões e tendências do comportamento eleitoral no } \\
\text { Rio Grande do Sul (1975) } \\
\text { Confrontação política e decisão eleitoral (1978) }\end{array}$ \\
\hline
\end{tabular}




\begin{tabular}{|c|c|c|}
\hline Período & Principais autores & Principais obras \\
\hline & $\begin{array}{l}\text { Martinez-Alier e Boito } \\
\text { Jr. } \\
\text { Wanderley Guilherme } \\
\text { dos Santos } \\
\text { Tereza Pires Caldeira } \\
\text { Maria D'Alva Kinzo }\end{array}$ & $\begin{array}{l}\text { Enxada e voto (1975) } \\
\text { As eleições e a dinâmica do processo político brasileiro } \\
\text { (1977) } \\
\text { Para que serve o voto? (1980) } \\
\text { Representação política e sistema eleitoral no Brasil } \\
\text { (1980) }\end{array}$ \\
\hline
\end{tabular}

\begin{tabular}{|c|c|c|}
\hline Período & Principais autores & Principais obras \\
\hline $1981-1990$ & $\begin{array}{l}\text { Marcelo Baquero } \\
\text { Flavio Pierucci } \\
\text { Maria Tereza Sadek } \\
\text { Maria D'Alva Kinzo } \\
\text { Bolivar Lamounier } \\
\text { Bolivar Lamounier e } \\
\text { Rachel Meneguelo } \\
\text { Eli Diniz }\end{array}$ & $\begin{array}{l}\text { Abertura política e comportamento eleitoral nas elei- } \\
\text { ções de } 1982 \text { no Rio Grande do Sul (1984) } \\
\text { As eleições municipais de } 1985 \text { (1986) } \\
\text { As bases da nova direita (1987) } \\
\text { A direita mora do outro lado da cidade (1989) } \\
\text { Eleições } 1986 \text { (1989) } \\
\text { Oposição e autoritarismo (1988) } \\
\text { De Geisel a Collor: o balanço da transição (1990) } \\
\text { Partidos políticos e consolidação democrática (1986) } \\
\text { Voto e máquina política (1982) }\end{array}$ \\
\hline $1991-2002$ & $\begin{array}{l}\text { Marcus Figueiredo } \\
\text { Antônio Lavareda } \\
\text { Flavio Silveira } \\
\\
\text { Bolivar Lamounier } \\
\text { Marcelo Baquero } \\
\text { Moacir Palmeira e Irlys } \\
\text { Barreira } \\
\text { Irlys Barreira } \\
\text { Nara Magalhães } \\
\text { Karina Kuschnir } \\
\text { Flavio Pierucci e M.C. } \\
\text { Lima } \\
\text { Flavio Pierucci } \\
\text { Rachel Meneguelo } \\
\text { Rachel Meneguelo, } \\
\text { Scott Mainwaring e T. } \\
\text { Power } \\
\text { André Singer } \\
\text { José Álvaro Moisés } \\
\text { Céli Regina Pinto }\end{array}$ & $\begin{array}{l}\text { A decisão do voto: democracia e racionalidade (1991) } \\
\text { A democracia nas urnas (1991) } \\
\text { Escolha intuitiva: uma nova modalidade de decisão } \\
\text { eleitoral (1994) } \\
\text { A decisão do voto no Brasil (1998) } \\
\text { A decisão eleitoral: imagem mídia e marketing (1999) } \\
\text { A dimensão simbólica da escolha eleitoral (2000) } \\
\text { Estratégia, mídia e voto (2002) } \\
\text { Depois da transição: democracia e eleições no governo } \\
\text { Collor (1991) } \\
\text { Transição, eleições e opinião pública (1995) } \\
\text { Candidatos e candidaturas: enredos de campanha } \\
\text { eleitoral no Brasil (1998) } \\
\text { Chuva de papéis: ritos e símbolos de campanhas eleito- } \\
\text { rais no Brasil (1998) } \\
\text { O povo sabe votar: uma visão antropológica (1998) } \\
\text { Eleições e representação no Rio de Janeiro (2000) } \\
\text { A direita flutuante (1991) } \\
\text { São Paulo, 1992: a vitória da direita (1993) } \\
\text { Ciladas da diferença (1999) } \\
\text { Partidos e governos no Brasil contemporâneo (1998) } \\
\text { Partidos conservadores no Brasil contemporâneo } \\
\text { (2000) } \\
\text { Esquerda e direita no eleitorado brasileiro (2000) } \\
\text { Os brasileiros e a democracia (1995) } \\
\text { O clientelismo eletrônico: a eficácia de um programa } \\
\text { popular de rádio (1993) } \\
\text { Ao eleitor a verdade: o discurso político da imprensa } \\
\text { em tempo de eleições (1995) }\end{array}$ \\
\hline
\end{tabular}




\begin{tabular}{|c|c|c|}
\hline Período & Principais autores & Principais obra \\
\hline & $\begin{array}{l}\text { Rubens Figueiredo } \\
\text { Rodolfo Grandi, } \\
\text { Alexandre Marins e } \\
\text { Eduardo Falcão } \\
\text { Adauto Novaes } \\
\text { Heloiza Matos } \\
\text { Mauro Porto } \\
\text { Afonso de } \\
\text { Albuquerque } \\
\text { Antônio Albino Rubim } \\
\text { Vera Chaia }\end{array}$ & $\begin{array}{l}\text { A conquista do voto (1994) } \\
\text { O que é marketing político? (1994) } \\
\text { Marketing político e persuasão eleitoral (2000) } \\
\text { Voto é marketing... o resto é política (1992) } \\
\text { Rede imaginária: televisão e democracia (1991) } \\
\text { Mídia, eleições e democracia (1994) } \\
\text { As eleições municipais em São Paulo (1994) } \\
\text { Política versus televisão: o horário gratuito na } \\
\text { campanha presidencial de 1994 (1995) } \\
\text { Mídia e política no Brasil (1999) } \\
\text { Mídia e eleições 98 (2000) } \\
\text { A liderança política de Jânio Quadros (1992) } \\
\text { Mídia e política (2000) }\end{array}$ \\
\hline
\end{tabular}

\section{As pesquisas eleitorais produzidas pelos institutos}

As pesquisa eleitorais começaram a ser produzidas no Brasil na década de 1940. O Ibope, criado em 1942, realizou a primeira pesquisa de intenção de voto em maio de 1945, junto a 1000 eleitores de São Paulo, sobre as eleições presidenciais. No período de 1945 a 1965, o Ibope realizou um volume considerável de pesquisas, cobrindo as principais eleições para cargos majoritários. No período do regime militar, as pesquisas de intenção de voto minguaram, em função da inexistência de eleições para os principais cargos majoritários (presidência da república, governo do estado e prefeitura das capitais e das cidades consideradas áreas de segurança nacional), do interesse relativamente menor pelas eleições proporcionais e pelas dificuldades financeiras e operacionais para a realização de pesquisas para cargos proporcionais. São necessárias amostras muito grandes para mensurar adequadamente as preferências em relação aos candidatos proporcionais, especialmente no caso das assembléias legislativas estaduais, em função da dispersão decorrente do grande o volume de candidatos e do fenômeno das votações concentradas em redutos eleitorais. A partir de 1982, com as eleições diretas para o governo dos estados e de 1985 com as eleições diretas para a prefeitura das capitais, as pesquisas eleitorais foram retomadas e produzidas em larga quantidade e de forma sistemática. Além dos institutos Ibope e Gallup já existentes, foram criados outros (Datafolha, Vox Populi, Toledo e Associados, entre outros), e as pesquisas acompanharam, com varias tomadas, os diversos processos eleitorais realizados deste período até o memento atual.

As experiências dos institutos de pesquisa no período das primeiras eleições diretas para cargos majoritários (1982 - 1985) provocaram muitas dúvidas e questionamentos. A credibilidade das pesquisas eleitorais estava muito abala- 
da, em função de graves erros de previsão de algumas pesquisas, não justificados pelas margens de erro previstas, de acordo com os parâmetros da teoria probabilística.

Tabela 1:

Eleições para a Prefeitura de Fortaleza em 1985

\begin{tabular}{|l|c|c|c|}
\hline \multicolumn{1}{|c|}{ Fortaleza } & $\begin{array}{c}\text { Gallup } \\
(\mathbf{2 0 / 1 0})\end{array}$ & Ibope (27/10) & Resultado \\
\hline Maria Luiza Fontanelle (PT) & $10 \%$ & $7 \%$ & $32 \%$ \\
\hline Paes de Andrade (PMDB) & $50 \%$ & $53 \%$ & $30 \%$ \\
\hline
\end{tabular}

Fonte: Gallup, Ibope

Tabela 2:

Eleições para a Prefeitura de Goiania em 1985

\begin{tabular}{|l|c|c|c|}
\hline \multicolumn{1}{|c|}{ Goiania } & Gallup (20/10) & Ibope (27/10) & Resultado \\
\hline Darci Accorsi (PT) & $11 \%$ & $11 \%$ & $45 \%$ \\
\hline Daniel Antônio (PMDB) & $57 \%$ & $60 \%$ & $40 \%$ \\
\hline
\end{tabular}

Fonte: Gallup, Ibope

Tabela 3:

Eleições para a Prefeitura de Recife em 1985

\begin{tabular}{|l|c|c|c|}
\hline \multicolumn{1}{|c|}{ Recife } & Gallup (20/10) & Ibope (27/10) & Resultado \\
\hline Jarbas Vasconcelos (PSB) & $24 \%$ & $21 \%$ & $33 \%$ \\
\hline Sérgio Murilo (PMDB) & $33 \%$ & $37 \%$ & $28 \%$ \\
\hline
\end{tabular}

Fonte: Gallup, Ibope

Em outros casos, como nas eleições para a Prefeitura de São Paulo em 1985, as diferenças entre os candidatos eram estatisticamente insignificantes, mas o modo de divulgação dos resultados indicava a vitória de um deles. Fernando Henrique Cardoso (PMDB), favorito nas pesquisas às vésperas do pleito, foi derrotado nas urnas. Carlos Matheus, do GALLUP, chegou a anunciar, na ocasião, na Rede Globo de Televisão que, segundo um levantamento de boca-de-urna, Fernando Henrique Cardoso venceria as eleições por $38 \%$ contra $37 \%$ dos votos. Horas depois, a mesma emissora divulgou os resultados oficiais parciais que já tornavam evidente a vitória de Jânio Quadros. Como interrogou pertinentemente Michel Thiollent (1989): "se todos sabiam que havia empate técnico entre os dois principais candidatos, por que alguns institutos afirmaram ou deixaram a impressão de que o primeiro iria ganhar?" 
Os dirigentes dos institutos de pesquisa que apresentaram dados muito distintos dos resultados oficiais das eleições não explicaram, na época, de forma satisfatória, os motivos dos equívocos de alguns dos resultados das pesquisas eleitorais divulgados na imprensa. Candidatos e dirigentes políticos de diferentes partidos manifestaram-se publicamente questionando a validade das pesquisas. Algumas das críticas e objeções formuladas demonstravam desconhecimento técnico sobre o assunto e careciam de fundamentação convincente. É o caso das dúvidas sobre a possibilidade técnica de as pesquisas anteciparem adequadamente os resultados a serem verificados nas próprias eleições. É o caso também da desconfiança em relação aos resultados da pesquisa em função da divergência entre estes dados e as informações obtidas através de outras formas de captar as vontades do eleitorado. No primeiro caso estamos diante de uma crítica ingênua, que releva desconhecimento sobre as técnicas de amostragem e sobre o conjunto de experiências realizadas por estatísticos e por centros de pesquisa, acadêmicos e privados, em muitos países. No segundo caso estamos diante de um pressuposto insustentável: de que as impressões de candidatos e políticos nas ruas possam ser mais precisas do que os resultados de levantamentos quantitativos realizados com amostras representativas dos universos investigados. O candidato precisa, necessariamente, estar convencido das suas chances de crescimento e de vitória (se ele mesmo não estiver convencido, é muito difícil que seja capaz de convencer os eleitores). Muitas das pessoas com que os candidatos têm contato pessoal nas ruas, estabelecem este contato por simpatizar com o candidato, ou, mesmo não simpatizando, sentem-se constrangidas em manifestar sua posição contrária. Em função da sua inserção na disputa os candidatos têm impressões muito distintas do quadro real da relação de forças entre os concorrentes.

Outras objeções à validade das pesquisas, então formuladas, apoiavam-se em suposições que dificilmente poderiam ser verificadas. É o caso da tese da parcialidade dos institutos de pesquisa em função de alianças políticas ou de vantagens econômicas. Se algum dirigente de um Instituto tivesse manipulado intencionalmente os dados de uma pesquisa para o favorecimento de um candidato em algum momento da campanha eleitoral esta situação seria mantida em sigilo pelas partes envolvidas e somente poderia ser revelada se tivesse sido feito, na ocasião, um trabalho sério de verificação dos questionários, teste de consistência dos dados coletados, inquirição dos entrevistadores, verificação dos métodos, das técnicas e dos procedimentos adotados. As suposições da tese da parcialidade chocam-se com o fato conhecido de que o principal capital de um instituto de pesquisa é a sua credibilidade. $O$ instituto que manipular intencionalmente os dados para beneficiar um aliado ou para obter vantagem econômica está arriscando a sua sobrevivência como empresa. Diferentemente de outros tipos de pesquisa, o levantamento eleitoral tem um parâmetro compara- 
tivo objetivo que é o resultado da contagem dos votos do universo do público investigado. Que empresa contrataria os serviços de pesquisa de um instituto que apresentou prognósticos eleitorais incorretos?

Suposições inconsistentes, a falta de conhecimento técnico, interesses políticos contrariados e a perda de credibilidade das pesquisas em função dos erros em eleições anteriores e do modo equivocado de apresentar os resultados na mídia contribuíram para fomentar um movimento contrário à divulgação das pesquisas eleitorais. A maior parte das críticas formuladas convergia para a tese de que a considerável influência exercida pelas pesquisas poderia ter um papel prejudicial de deformação da disputa eleitoral, uma vez que os duvidosos resultados dos levantamentos, tomados como verdadeiros, moldariam o comportamento do eleitor. O eleitorado, assim, seria induzido a votar em determinados candidatos projetados pelas pesquisas eleitorais. Esta tese obteve grande aceitação no meio político, estimulando a aprovação no Congresso, em 1989, de uma lei que proibia a divulgação de resultados de pesquisas eleitorais durante os 30 dias que antecediam as eleições. Esta lei não foi aplicada somente porque o Supremo Tribunal Eleitoral a considerou inconstitucional.

Durante este período, os dirigentes dos institutos, acuados frente às tentativas de restrição legal à divulgação das pesquisas, assumiram uma postura defensiva neste debate: limitaram-se a afirmar a "cientificidade" das pesquisas e a negar influência exercida por elas nos processos eleitorais. Posteriormente, a partir de 1991, dirigentes e técnicos de institutos de pesquisas, assim como pesquisadores da área acadêmica, adotaram uma atitude mais ofensiva e participaram ativamente do debate sobre o assunto, analisando a influência das pesquisas na decisão eleitoral através de vários artigos para jornais, revistas científicas e livros: O papel das pesquisas eleitorais, de Antônio Manuel Teixeira Mendes (1991); Pesquisas eleitorais e voto no Brasil, de Flavio Eduardo Silveira (1991), O uso de pesquisas eleitorais em decisões de voto: as eleições brasileiras de 1989, de Márcia Cavalli Nunes, Örjan Olsén e Joseph Straubhaar (1993); Contribuição para o conceito de opinião pública, de Rubens Figueiredo e Sílvia Cervellini (1995); O papel das pesquisas, de Márcia Cavalli Nunes (2000); Como são feitas as pesquisas eleitorais e de opinião, de Carlos Alberto Almeida (2002).

A tese da influência perniciosa das pesquisas mostrou-se frágil frente aos argumentos desenvolvidos. A tese supõe um eleitorado imbecilizado, sem capacidade de decidir autonomamente, que segue mecanicamente às tendências apontadas pelas pesquisas (Silveira 1991). Se este fosse o comportamento do eleitorado, o candidato que despontasse inicialmente nas pesquisas tenderia a vencer as eleições. Mas não é isto que observamos em parte considerável dos processos eleitorais. As posições dos candidatos na disputa se alteram e o jogo 
eleitoral apresenta reais condições de incerteza. Não se pode saber, no início da campanha eleitoral, quem será o candidato vencedor do pleito.

É muito difícil mensurar o chamando "efeito bandwagon", isto é, a tendência do eleitor votar no candidato que parece como provável vencedor; do mesmo modo como é difícil mensurar o "efeito underdog", a tendência inversa do eleitor apoiar o mais fraco (Lavrakas e Traugott 2000). As pesquisas empíricas realizadas têm encontrado dificuldades em medir isoladamente a influência do fator pesquisa eleitoral, considerando que vários outros fatores exercem simultaneamente considerável influência sobre os eleitores em uma escolha eleitoral (Nunes, Olsén e Straubhaar 1993). Em pesquisa realizada no Brasil em 1989 verificou-se que $15,7 \%$ (em uma amostra de 2680 casos) admitiram ter usado as pesquisas eleitorais em suas decisões de voto na eleição estudada ou em eleições passadas. Parte destes (7,2\% do conjunto da amostra) indicaram um comportamento do tipo bandwagon e proporção similar correspondeu à tendência do voto underdog (Nunes, Olsén e Straubhaar 1993). Estes resultados são similares aos encontrados em pesquisa realizada em 1994, no Rio Grande do Sul, pelo Instituto Meta. Neste levantamento, apenas 5,8\% dos eleitores admitiram ter tido importância na sua decisão do voto o fato do candidato estar na frente nas pesquisas eleitorais.

Um grupo considerável de eleitores atribui pouca importância às probabilidades eleitorais porque decide o seu voto em função de outros critérios como a imagem dos candidatos, a identificação com lideranças políticas, a avaliação do desempenho dos governos, os vínculos clientelistas, as experiências políticas vividas, a preferência partidária, entre outros. Entre os eleitores que consideram importantes as probabilidades eleitorais, uma parte deles não utiliza as informações das pesquisas para seguir as tendências majoritárias, mas para potencializar, através de um cálculo racional, suas preferências no jogo político-eleitoral. Este último é o argumento utilizado por Mendes (1991) para sustentar que as pesquisas divulgadas nos meios de comunicação constituem um importante instrumento de democratização de informações. Com base nestas informações o eleitor poderia agir de forma racional, deixando de votar em um candidato preferido que não tem chances de vencer e optar pelo segundo na sua ordem de preferência, para evitar a vitória de um terceiro que ele rejeita.

A escolha racional corresponde ao comportamento de apenas uma parte do eleitorado. Em geral, corresponde ao comportamento dos eleitores mais sofisticados e politicamente envolvidos. As proporções de eleitores que utilizam recursos e atalhos racionais como elementos relevantes de sua decisão de voto podem variar em diferentes contextos eleitorais. É muito conhecido o fenômeno do "voto útil" que, em certos processos eleitorais, constitui uma forma de decisão adotada por uma parte considerável dos eleitores. De qualquer forma, 
sejam as escolhas orientadas por estratégias racionais ou por elementos de natureza distinta (juízos de gosto, sensibilidades, intuições, emoções ou imagens), é aceitável o argumento de que as pesquisas produzem dados relevantes que são constituintes do ambiente de informações no qual a decisão eleitoral é tomada (Meyer 1989). Do mesmo modo que as informações fornecidas pelos candidatos e dirigentes políticos e pelos meios de comunicação, os dados fornecidos pelos Institutos de Pesquisa constituem elementos legítimos, formadores do cenário da campanha eleitoral. A utilização destas informações depende do modo como cada eleitor pensa o mundo político e decide o seu voto. Mas é importante para um regime democrático que estas informações circulem livremente e que os eleitores possam ter acesso a elas e, se for o caso, que possam utilizá-las da maneira que considerem mais conveniente.

A maior influência das pesquisas eleitorais não é exercida diretamente sobre a base de eleitores. A influência indireta é relevante no caso das pesquisas contratadas pelos comitês de campanha dos candidatos. Os resultados destas pesquisas, não divulgados, são essenciais para o estabelecimento das estratégias dos candidatos, para a identificação dos pontos vulneráveis dos adversários e das formas mais eficientes de sensibilizar o público e conquistar adesões. Outra influência indireta importante refere-se às fontes de financiamento das campanhas e à mobilização da militância. Os candidatos que aparecem bem posicionados nas pesquisas conseguem obter mais apoio político, maior contribuição financeira para suas campanhas, mais espaço nos meios de comunicação e maior mobilização das suas bases de sustentação partidária. Ao contrário, aqueles que não logram resultados favoráveis são submetidos a restrições progressivas nos espaços da disputa, o que pode acarretar em desmobilização política (Silveira 1991; Almeida 2002).

Os esclarecimentos sobre as formas de influência das pesquisas eleitorais nas decisões do voto feitos através de vários trabalhos empírica e teoricamente bem fundamentados, e apoiados em experiências e em reflexões desenvolvidas no meio acadêmico, foram importantes para relativizar as convicções e crenças tendentes a superdimensionar a influência das pesquisas e a atribuir a esta influência uma conotação negativa observadas como majoritárias no meio político e na população em geral. Estudos mostraram o considerável crescimento da credibilidade das pesquisas a partir dos anos 90 (Mendes 1991; Nunes, Olsén e Straubhaar 1993). Esta mudança ocorreu em um período em que os Institutos tornaram-se mais cuidadosos em seus procedimentos técnicos e metodológicos. Como resultado deste processo, houve uma sensível redução dos erros crassos nos episódios eleitorais que se seguiram. Os principais órgãos de pesquisa apresentaram, nas quatro eleições presidenciais seguintes $(1989,1994,1998$ e 2002), resultados dos seus últimos levantamentos muito próximos aos resultados oficiais do Tribunal Superior Eleitoral. Contudo, continuaram a ser produ- 
zidos pelos institutos alguns resultados de pesquisas eleitorais discrepantes dos dados oficiais, especialmente em relação a algumas situações regionais. Entre os casos recentes mais rumorosos, destaca-se o equívoco do Ibope nas eleições para o governo do Estado do Rio Grande do Sul em 2002. Na pesquisa de boca-de-urna do segundo turno das eleições, com uma amostra relativamente grande (3200 entrevistas, considerando o intervalo de confiança de $95 \%$ e a margem de erro amostral de 1,69\%), o Ibope encontrou uma diferença de 12 pontos percentuais entre o primeiro colocado (Germano Rigotto) e o segundo colocado (Tarso Genro). No mesmo episódio apresentaram diferenças muito próximas às verificadas nos resultados oficiais do Tribunal Regional Eleitoral o Centro de Pesquisas do jornal Correio do Povo (5 pontos percentuais) e a Meta Instituto de Pesquisa (4,5 pontos percentuais).

Existem inúmeras possibilidades de erro em pesquisa eleitoral. Os erros referem-se, em menor proporção, ao desenho do plano amostral. Geralmente o cálculo do tamanho e da distribuição da amostra é feito de forma adequada pelos institutos especializados. Os erros mais relevantes geralmente observados referem-se aos problemas epistemológicos e teórico-metodológicos, à concepção do instrumento de pesquisa, à interpretação dos dados, ao controle do trabalho de campo e ao modo de divulgar os resultados do levantamento.

O primeiro problema que merece ser mencionado tem natureza epistemológica e refere-se aos efeitos do processo de quantificação de opiniões. Trata-se de um processo de simplificação. Opiniões correspondem ao resultado de processos complexos e diferenciados que envolvem as percepções do mundo social e político, a lógica que orienta a produção de opiniões, os vínculos socialmente estabelecidos, a identidade política construída e a cultura política dos diferentes setores do eleitorado. A mesma opinião sintética sobre um determinado assunto pode ser composta por elementos e processos produtores diferenciados. Muitos estudos mostram que grupos consideráveis de eleitores apresentam fraca inter-relação lógica entre idéias políticas (Silveira 1998). Algumas idéias estão fundadas em experiências práticas, outras decorrem de relações intersubjetivas, outras são produto de relações afetivas e, outras ainda estão associadas às relações de interesse. Algumas opiniões são mantidas por um indivíduo como convicções, enquanto outras não passam de simples impressões. Estas últimas estão mais sujeitas às mudanças. Grande parte dos eleitores muda de opinião, com grande facilidade, em determinadas situações. Opiniões e intenções que possuem idêntica expressão podem ser produto de processos de decisão diferenciados. É totalmente distinta a situação de um eleitor que irá votar num candidato por estar fortemente comprometido com ele (por razões de fidelidade política, por exemplo) e de outro eleitor que afirma sua intenção de votar no mesmo candidato porque tem uma leve simpatia por ele, ou porque o considera o menos pior (neste caso a opinião poderá mudar mais facilmente). 
O grande problema é considerar como uniformes, para efeito de quantificação, opiniões aparentemente equivalentes, mas que são, aos olhos de um exame mais profundo, muito distintas, em relação ao seu processo de constituição, aos seus elementos motivadores.

Reconhecer este problema, inerente às metodologias de pesquisa de natureza quantitativa, não implica questionar a utilidade destas metodologias, nem tampouco dos fundamentos estatísticos, ao estilo do trabalho $A$ ilusão das estatísticas, organizado por Jean-Louis Besson (1995). Embora possamos encontrar neste trabalho algumas críticas pontuais interessantes, grande parte das objeções apontadas não é procedente e demonstra pouco conhecimento da teoria probabilística e das experiências desenvolvidas na área estatística. Tampouco é pertinente a afirmação de Patrick Champagne (1998) de que as pesquisas constituem ilusões bem fundamentadas. A principal fonte de legitimação da estatística e das pesquisas não são teorias bem fundamentadas, mas o acerto empírico, dentro das margens de erro previstas, observado ao longo de décadas de atividade. Se os fundamentos estatísticos e as pesquisas correspondessem a ilusões, por que os agentes que tomam decisões no mundo privado e público usariam estes recursos? Também não é procedente a crítica formulada por Bourdieu de que as pesquisas equivocam-se ao atribuir igual peso a opiniões que tem força diferente na sociedade. As opiniões efetivamente não têm o mesmo peso e nem todos os indivíduos são produtores de opinião. Mas as pesquisas reproduzem a mesma situação real das eleições. Isto é, indivíduos com diferentes níveis de saber político, influenciados por vários fatores e agentes que constituem o cenário de informação da disputa eleitoral (propaganda eleitoral, cobertura das eleições através da mídia, discursos dos candidatos, conversas com amigos etc.), manifestam sua intenção e emitem sua opinião individualmente, do mesmo modo que indicam o seu voto nas urnas.

As metodologias de pesquisa de natureza quantitativa são muito úteis. Mas, como outras formas de investigação, apresentam limites. É útil ao pesquisador conhecer estes limites, para poder manejar de forma adequada este instrumento de conhecimento e para poder extrair o máximo proveito dele, sem incorrer, por desatenção aos problemas de caráter epistemológico e teóricometodológico, em erros na formulação e na interpretação das questões. Os efeitos do processo de simplificação, uniformização e quantificação de opiniões, próprio das pesquisas quantitativas, podem ser, em parte, controlados, através de um cuidadoso trabalho de elaboração das questões e da utilização de mecanismos complementares de captação de informações. É importante abordar um problema de pesquisa sob vários ângulos, de modo a poder dimensionar a relevância dos fatores motivadores da opinião emitida e de outros fatores contextuais pertinentes em uma dada situação. Ao invés de uma única pergunta direta sobre o assunto, o pesquisador poderá formular várias perguntas que 
cercam o problema, medindo algumas das suas hipóteses sobre o assunto. Além da opinião propriamente dita, é interessante verificar os elementos a ela associados, as fontes de informação utilizadas, as justificativas apresentadas para sustentar a opinião emitida e o grau de cristalização da opinião. Este conjunto de elementos fornece maior segurança ao pesquisador para a posterior análise dos dados, permitindo a ele perceber as possibilidades de mudança de certas opiniões e as características e tendências desta mudança. Em alguns casos, a combinação de um levantamento quantitativo e de uma pesquisa qualitativa é muito útil para a interpretação dos acontecimentos. Dependendo da situação, poderá se mostrar necessário o desenvolvimento de outros mecanismos complementares de captação de informações.

Outros problemas teórico-metodológicos importantes referem-se aos efeitos da chamada "imposição da problemática" (Bourdieu 1983) e da desconsideração das diferenças culturais e dos problemas de comunicação entre pesquisador e entrevistado. Muitas vezes, as perguntas formuladas pelo pesquisador referem-se a assuntos pouco ou nada conhecidos ou não são questões relevantes para o entrevistado. Quando perguntamos algo desconhecido ou considerado irrelevante, os entrevistados formulam respostas inadequadas. Quando os entrevistados não compreendem propriamente o significado das questões formuladas, eles não respondem (elevando os percentuais das não-respostas), respondem de modo aquiescente ou reproduzem as opiniões mais correntes. Ao formular as perguntas e as alternativas prováveis, o pesquisador deve levar em consideração que não existem problemas que se apresentem de igual modo para todos e o significado das perguntas pode ser interpretado de formas diferentes. Se o pesquisador desconsiderar essas diferenças, ele poderá obter respostas superficiais ou inadequadas, limitadas à reprodução artificial de suas próprias hipóteses e opiniões anteriores. Além de considerar os distintos níveis de interesse, de informação e de conhecimento, o pesquisador deve considerar as diferenças culturais e sociais. Isto não significa, para o pesquisador, apenas procurar "traduzir" as palavras mais "abstratas" e "sofisticadas" em palavras mais "concretas" e "simples". Em muitos casos é necessário reformular os termos dos problemas, para que a leitura de opiniões realizada seja fiel às opiniões da população investigada.

O problema da elaboração das perguntas de um instrumento é extremamente relevante e pode ser fator importante de erros de interpretação. O excelente trabalho Como perguntar: teoria e prática da construção de perguntas em entrevistas e questionários de William Foddy (1996) mostra como a mudança nos termos de uma pergunta, com a manutenção de conteúdo semelhante, altera completamente os resultados obtidos. Em uma pesquisa feita na Inglaterra pelo Nacional Opinion Polls a formulação "Você aceita a recomendação do Governo de que o Reino Unido deve sair do Mercado Comum Europeu?" teve como 
resultado um "empate técnico" (as opiniões contrárias e favoráveis apresentaram proporções semelhantes). Já com a formulação "Você aceita a recomendação do Governo de que o Reino Unido deve ficar no Mercado Comum Europeu?" as respostas favoráveis superaram as contrárias, com uma diferença de 18,2\%. Experiências de pesquisas realizadas no Brasil pelo Instituto Meta corroboram as afirmações do autor. Quando perguntamos, por exemplo, se o eleitor considera que o seu voto foi influenciado pelos meios de comunicação, as proporções de respostas negativas encontradas são, geralmente, muito elevadas, alcançando quase a totalidade do eleitorado. Mas quando perguntamos se os meios de comunicação ajudam o eleitor a escolher o seu candidato, as proporções de respostas positivas encontradas correspondem, geralmente, a cerca de metade do eleitorado. Quando formulamos uma pergunta, há um processo de codificação, isto é, a transformação das idéias interligadas, por vezes complexas, constituintes de um problema de pesquisa em uma (ou em várias) pergunta(s) específica(s) simples. O entrevistado decodifica a pergunta, isto é, atribui significados aos termos da pergunta e interpreta estes significados. Há um novo processo de codificação quando o entrevistado responde a pergunta, transformando as suas idéias em palavras ou frases simples. E há um novo processo de decodificação quando o pesquisador interpreta o significado das respostas dos entrevistados. Não são pequenas as possibilidades de ocorrência de problemas de comunicação nestes processos de codificação e de decodificação que marcam a relação entre pesquisador e entrevistado.

Além das diferenças decorrentes dos termos utilizados nas perguntas, existem vários outros problemas relativos à construção do instrumento recorrentemente observados na experiência das pesquisas eleitorais. São freqüentes os problemas de interpretação das perguntas formuladas pelos entrevistados. A ordem das perguntas pode alterar o conteúdo das respostas. A ordem das alternativas pré-codificadas como possíveis respostas a uma pergunta pode afetar a manifestação do entrevistado. Mesmo não estando familiarizado com o tema proposto, os entrevistados geralmente respondem às perguntas formuladas. As opiniões dos entrevistados são instáveis e podem mudar em um curto espaço de tempo, dependendo da emergência de novos fatos e outros fatores motivacionais. A capacidade de conceptualização da maior parte dos entrevistados é pequena, assim como a capacidade de inter-relacionar adequadamente idéias políticas. Também é fraca a relação entre o que os entrevistados dizem e o que eles efetivamente fazem.

O pesquisador deve considerar este conjunto de problemas e tendências comportamentais para formular adequadamente o instrumento de pesquisa e interpretar os dados coletados. Não pode emitir um juízo sobre o quadro eleitoral baseando-se somente em um aspecto. É muito comum em pesquisas eleitorais atribuir demasiada importância à chamada menção induzida, instrumento 
usual de medição das intenções de voto, geralmente utilizado para a divulgação, pelos meios de comunicação, da situação da disputa eleitoral. A menção induzida corresponde à escolha que o entrevistado faz mediante a apresentação dos nomes dos prováveis candidatos. Neste caso, muitos entrevistados que estavam indecisos na menção espontânea (sem a apresentação dos nomes), podem responder em função de leve inclinação, ou escolhendo os candidatos mais conhecidos, somente para corresponder às expectativas do que ele julga ser um comportamento aceitável em uma entrevista. Especialmente quando são apresentadas inúmeras hipóteses de oferta eleitoral, os entrevistados acabam por indicar alguma preferência, evitando a constrangedora resposta negativa para as várias hipóteses apresentadas. Os dados da menção espontânea são os mais confiáveis para indicar intenção de voto, mas geralmente são pouco divulgados, porque até as últimas semanas o percentual de indecisos é muito elevado e a diferenciação entre os candidatos mais fortes tende a ser pequena. Uma avaliação mais confiável das tendências eleitorais deve considerar não só a intenção de voto declarada, mas também outros elementos como a imagem dos candidatos, o grau de rejeição, o grau de "cristalização" do voto, a tendência de voto dos indecisos e o impacto de questões relevantes para a disputa eleitoral.

A consideração de diferentes aspectos da disputa eleitoral amplia a capacidade preditiva da análise dos dados, possibilitando ao pesquisador captar certas mudanças repentinas. A maior parte das dificuldades dos principais institutos em diagnosticar adequadamente as tendências eleitorais refere-se a estas mudanças de percepção e de intenção dos eleitores. Parte considerável dos erros crassos de prognóstico eleitoral foi observada em situações de mudança de hegemonia política ou de crescimento repentino e acentuado de certos candidatos. Nas eleições de 1985 para a Prefeitura de São Paulo, foi observado o fenômeno do voto "envergonhado" em Jânio Quadros (eleitores que pretendiam votar em Jânio Quadros omitiam a sua intenção publicamente, por acreditarem que esta opção não era socialmente aceita). Nas eleições de 1988 para a Prefeitura de São Paulo, a maior parte dos Institutos não conseguiu captar o enorme crescimento da candidatura de Luíza Erundina na última semana anterior à votação. Nas eleições para a Prefeitura de Porto Alegre em 1988 o candidato eleito Olívio Dutra, nas várias pesquisas divulgadas durante quase toda campanha eleitoral, não havia obtido mais que $15 \%$ das intenções de voto, e Antônio Britto e Guilherme Socias Villela lideravam com percentuais bem mais elevados. Algumas pesquisas, como as contratadas por Olívio Dutra, conseguiram captar as tendências de crescimento do candidato petista três semanas antes das pesquisas dos demais Institutos, que somente previram a vitória folgada do candidato petista em seus últimos levantamentos de boca-de-urna. 
Outra possível fonte de distorções e erros refere-se ao trabalho de campo. Podem ocorrer vários tipos de problemas. Os entrevistadores nem sempre compreendem perfeitamente o sentido de cada pergunta do questionário, assim como das alternativas pré-codificadas. As falhas podem ser decorrentes de erros do treinamento realizado, ou da capacidade limitada de algumas das pessoas escolhidas para realizar esta função. Além das explicações do treinamento são importantes os experimentos práticos para verificar a efetiva compreensão do entrevistador, especialmente no caso de questionários complexos, que envolvem "pulos" e a interpretação do sentido das respostas. São necessários, também, um criterioso processo de seleção e um sistema permanente de avaliação do desempenho dos entrevistadores. As situações de campo levam, muitas vezes, os entrevistadores à busca das saídas mais fáceis e dos caminhos mais rápidos, que, na maior parte das vezes, não são os mais adequados do ponto de vista técnico. São comuns os erros de leitura de alternativas quando o enunciado da questão alerta para que isto não seja feito, de preenchimento incorreto das cotas, com a alteração das características do entrevistado, de não observância dos critérios de contagem dos domicílios, de indução do entrevistado à resposta não sabe/não respondeu, como forma de agilizar a aplicação do questionário, entre inúmeros outros. Os institutos especializados realizam a "checagem" dos questionários (em geral, cerca de $20 \%$ a $30 \%$ ), a revisão dos questionários preenchidos, a verificação da consistência dos dados e um conjunto de mecanismos de controle para supervisionar o trabalho do entrevistador, evitar fraudes e minimizar os erros. A precisão dos dados coletados depende da qualidade destes mecanismos de treinamento, controle e verificação.

Por fim, também merece ser mencionado o problema da incorreta interpretação dos resultados das pesquisas expressa na forma de divulgação dos dados. Muitas vezes os resultados das pesquisas eleitorais são enviados aos jornalistas, que elaboram as matérias e as manchetes. Embora alguns jornalistas tenham conhecimento técnico sobre pesquisas eleitorais, muitos outros desconhecem aspectos básicos e não sabem interpretar corretamente os dados de pesquisas. Há também o interesse do jornal em produzir manchetes com forte apelo, para atrair maior número de leitores. É muito comum a situação, comentada por Alberto Almeida (2002), dos jornalistas caírem na "tentação de divulgar pequenas mudanças nos índices de intenção de voto como se fossem grandes mudanças". O modo como foram divulgados os resultados das pesquisas nos principais jornais do país contribuíram para ampliar a crise de credibilidade dos institutos, especialmente no período do final dos anos 80 e início dos anos 90. Faltando apenas quatro dias para as eleições para a prefeitura de São Paulo em 1988, o jornal $O$ Estado de São Paulo afirmou na manchete da matéria sobre os resultados da pesquisa do Ibope: "Maluf, em $1^{\circ}$, amplia a diferença" (Maluf teria $27 \%$ das preferências, contra 17\% de Leiva e 15\% de Erundina - 
que nas urnas foi vitoriosa). Faltando um mês para as eleições presidenciais de 1989, o Jornal da Tarde afirmou: "Pesquisa Gallup: Afif já ameaça desbancar Brizola" (Afif com 9,2\% das intenções de voto, teria superado Lula com 7,1\% e estaria perto de Brizola que possuía 15,2\%). Pouco tempo depois a súbita ascensão de Afif desapareceria sem deixar vestígios, e Lula superaria Brizola nas urnas. O jornal Folha de São Paulo, faltando cinco dias para as eleições para o governo do Rio Grande do Sul em 1990, afirmou: "No RS, Machezan cresce 6 pontos e é líder" (nas urnas Collares venceu por 2\% dos votos). Posteriormente os jornais tornaram-se mais cuidadosos, e buscaram evitar a divulgação de manchetes arriscadas, especialmente na primeira página. Mas problemas de incorreta interpretação dos resultados de pesquisas divulgados nos meios de comunicação continuam a ocorrer, ainda que em menor proporção.

O grau de precisão da pesquisa eleitoral, dentro da margem de erro e do intervalo de confiança previstos, depende, assim, de um conjunto de elementos referentes à qualidade do trabalho realizado. É importante que os coordenadores da pesquisa desenhem um plano amostral bem estruturado, estejam atentos e vigilantes em relação aos problemas epistemológicos e teóricometodológicos, desenvolvam um cuidadoso trabalho de elaboração do instrumento e de análise dos dados coletados, exerçam efetivo controle do trabalho de campo e participem do processo de transformação dos resultados em material de notícia, exigindo, dos meios de comunicação, que a forma de divulgação dos resultados não contrarie a interpretação técnica.

\section{Referências bibliográficas}

Albuquerque, Afonso de (1995). Política versus televisão: o horário gratuito na campanha presidencial de 1994. Comunicação \& Política, n. ${ }^{\circ} 3$, Rio de Janeiro: Cebela.

(1996). A batalha pela Presidência: o horário gratuito de propaganda eleitoral na campanha de 1989. Rio de Janeiro. Tese. Escola de Comunicação da Ufrj.

Almeida, Alberto Carlos (2002). Como são feitas as pesquisas eleitorais e de opinião. Rio de Janeiro, Editora FGV.

Amaral, Azevedo (1938). O estado autoritário e a realidade nacional. Rio de Janeiro: José Olímpio.

Atkin, Charles K., Bowen, L. e O. B. Nayman (1973). Quality versus quantity in televised political ads. Public Opinion Quartely. Chicago: American Association for Public Opinion Reserch/University of Chicago, v. 40. 
Azevedo, Fay (1957). Os partidos políticos no Rio Grande do Sul. Revista Brasileira de Estudos Políticos. Belo Horizonte, v. 1, n. ${ }^{\circ} 2$.

Babbie, Earl (1999). Métodos de pesquisa de survey. Belo Horizonte: Editora UFMG.

Baquero, Marcello (1984). As eleições de 1982 no Rio Grande do Sul no contexto de abertura política. In: Marcello Baquero (org.). Abertura política e comportamento eleitoral nas eleições de 1982 no RS. Porto Alegre: Editora da Universidade.

(1986). As eleições municipais de 1985. Revista de Ciências Sociais. Porto Alegre: Ed. Universidade, v. 1, n. $^{\circ} 1$.

(1994). O desencanto com a democracia: análise do comportamento eleitoral dos gaúchos nas eleições de 1994. XVIII Encontro Anual da Anpocs. Caxambu: Mimeo.

Barreira, Irlys (1998). Chuva de papéis: ritos e símbolos de campanhas eleitorais no Brasil. Rio de Janeiro: Relume-Dumará.

Besson, Jean-Louis (Org.) (1995). A ilusão das estatísticas. São Paulo: Editora da Unesp.

Blumler, Jay G. (1990). Elections, the media and the modern publicity process. In: Marjorie Gercuson. Public comunication: the new imperatives. London: Sage.

Bourdieu, Pierre (1979). La Distinction. Paris: Minuit. (1980). Le sens pratique. Paris: Minuit.

(1983). Questões de Socilogia. Rio de Janeiro: Marco Zero.

Butler, D. e D. Stokes (1969). Political change in Britain. London: Macmillan.

Cain, B., Ferejon, J. and M. Fiorina (1987). The personal vote: constituency service and electoral independence. Cambridge: Harvard University Press.

Caldeira, Tereza Pires do R. (1980). Para que serve o voto? As eleições e o cotidiano na periferia de São Paulo). In: Bolivar Lamounier (org.). Voto de desconfiança: eleições e mudança política no Brasil, 1970-1979. Petrópolis: Vozes.

Campbell, A. et al. (1964). The american voter. New York: John Wiley \& Sons. et al. (1966). Elections and the political order. New York: John Wiley \& Sons.

Carvalho, José Murilo de (1989). Eleições em tempo de cólera. Cadernos de Conjuntura. Rio de Janeiro: Iuperj, n. ${ }^{\circ} 20$.

Carvalho, Orlando M. de (1957). Ensaios de Sociologia Eleitoral. Revista Brasileira de Estudos Políticos. Belo Horizonte, v. 1, n. ${ }^{\circ} 2$.

Castro, Mônica Mata Machado de (1992). Sujeito e estrutura no comportamento eleitoral. Revista Brasileira de Ciências Sociais, n. ${ }^{\circ} 20$.

(1994). Determinantes do Comportamento Eleitoral: a centralidade da sofisticação política. Tese. Iuperj.

Cavalcanti, T. e Dubnic, R. (orgs.) (1964). Comportamento eleitoral no Brasil. Instituto de Direito Público e Ciência Política. Rio de Janeiro: Fundação Getúlio Vargas. 
Chaia, Vera (1992). A liderança Política de Jânio Quadros - 1947-1990. Ibitinga: Editora Humanidades.

Chaia, Vera et al. (2000). Mídia e política. São Paulo: Educ/Neamp.

Champagne, Patrick (1996). Formar opinião: o novo jogo político. Petrópolis: Vozes.

Cintra, A. O. (1968). Partidos políticos em Belo Horizonte: um estudo do eleitorado. Revista Dados, n. ${ }^{\circ}$.

Converse, Philipe E. (1964). The nature of bilief systems on mass publics. In: D. Apter (org.). Ideology and discontent. New York: The Free Press.

(1966). The problem of party distances in models of voting change. In: Jennings, M. Kent e Harman Zeigler (orgs). The electoral process. New York: Prentice-Hall.

(1966). The concept of normal vote. In: Campbell et al. Elections and the political order. New York: John Wiley \& Sons.

(1975). Public opinion and voting behavior. In: Fred I. Greenstein et al. Handbook of Political Science. Princeton: Addison-Wesley Publishing Company, v. 4.

Day, R. H. e T. Groves (1975). Adaptive economic models. New York: Academic Press.

Diniz, Eli (1982). Voto e máquina política: patronagem e clientelismo no Rio de Janeiro. Rio de Janeiro: Paz e Terra.

(1989). Partidos e crise política: as eleições presidenciais de 1989. Cadernos de Conjuntura. Rio de Janeiro: Iuperj, n. ${ }^{\circ} 20$.

(1994). O Brasil no rastro da crise. São Paulo: Anpocs/IPEA/Hucitec.

Downs, Anthony (1957). An economic theory of democracy. New York: Harper and Row.

Elster, Jon et al (1986). Rational Choice. New York: New York University Press.

(1987). Sour grapes: studies in the subversion of racionality. Cambridge: Cambridge University Press.

(1994). Peças e engrenagens das Ciências Sociais. Rio de Janeiro: RelumeDumará.

Faria, Vilmar E. (1975). As eleições de 1974 no Estado de São Paulo: uma análise das variações inter-regionais. In: B. Lamounier e F. H. Cardoso (orgs.). Os partidos políticos e as eleições no Brasil. Rio de Janeiro: Paz e Terra.

Ferreira, Oliveiros S. (1964). Comportamento eleitoral em São Paulo. Revista Brasileira de Estudos Políticos. Belo Horizonte, n. ${ }^{\circ} 8$.

Figueiredo, Marcus (1991). A decisão do voto: democracia e racionalidade. São Paulo: Sumaré/Anpocs.

(1995). Volatilidade Eleitoral em Eleições Parlamentares, 1946-1982. XIX Encontro Anual da Anpocs. Caxambu: Mimeo.

Figueiredo, M., et al. (2000). Estratégias de persuasão em eleições majoritárias: uma proposta metodológica para o estudo da propaganda eleitoral. In: R. Figueiredo 
(org.). Marketing político e persuasão eleitoral. São Paulo: Fundação Konrad Adenauer.

Figueiredo, Ney Lima (1994). Jogando para ganhar: marketing político: verdade e mito. São Paulo: Geração Editorial.

Figueiredo, Rubens (1994). O que é marketing político? São Paulo: Brasiliense.

Figueiredo, Rubens e Mauro Malin (Orgs.) (1994). A conquista do voto. São Paulo: Brasiliense.

Figueiredo, Rubens e Sílvia Cervellini (1995). Contribuição para o Conceito de opinião pública. Opinião pública, v. 3, n. $^{\circ} 3$.

Figueiredo, Rubens (org.) (2000). Marketing político e persuasão eleitoral. São Paulo: Fundação Konrad Adenauer.

Fiorina, M. (1981). Retrospective voting in american national elections. New Harven: Yale University Press.

Foddy, William (1996). Como perguntar: teoria e prática da construção de perguntas em entrevistas e questionários. Oeiras: Celta Editora.

Gaxie, Daniel (org.) (1985). Explication du vote. Un bilan des études électorales en France. Paris: Presses de la Fondation Nationale des Sciences Politiques.

Grandi, R. et al. (1992). Voto é Marketing...o resto é política. São Paulo: Loyola.

Habert, Philippe et al. (1992). Le vote éclaté. Paris. Presses de la Fondation Nationale des Sciences Politiques.

Himmelweit, Hilde T. et al. (1981). How voters decide. London: Academic Press Inc.

Jaguaribe, Hélio (1950). Política de clientela e política ideológica. Digesto Econômico, n. ${ }^{\circ} 68$.

Kinzo, Maria D'Alva Gil (1980). Representação política e sistema eleitoral no Brasil. São Paulo: Símbolo.

. (1988). Oposição e autoritarismo: gênese e trajetória do MDB (1966/1979). São Paulo: Idesp/Vértice.

Kuschnir, Karina (2000). Eleições e representação no Rio de Janeiro. Rio de Janeiro: Relume-Dumará.

Lamounier, Bolivar e Fernando Henrique Cardoso (orgs.) (1975). Os partidos e as eleições no Brasil. Rio de Janeiro: Paz e Terra.

(1975) Comportamento eleitoral em São Paulo: passado e presente. In: Lamounier, Bolivar e Cardoso, Fernando Henrique (orgs.). Os partidos e as eleições no Brasil. Rio de Janeiro: Paz e Terra.

(1978). Presidente Prudente: O crescimento da oposição num reduto arenista. In: Fábio Wanderley Reis (org.). Os partidos e o regime: a lógica do processo eleitoral brasileiro. São Paulo: Símbolo.

(org.) (1980). O voto de desconfiança: eleições e mudança social no Brasil 1970-1979. Petrópolis: Vozes. 
(1980). O voto em São Paulo, 1970-1979. In: Bolivar Laumonier. O voto de desconfiança: eleições e mudança política no Brasil 1970-1979. Petrópolis: Vozes. (1986). 1985: o voto em São Paulo. São Paulo: Idesp.

(org.) (1990). De Geisel a Collor: o balanço da transição. São Paulo: Sumaré/Idesp/CNPq.

(1991). Depois da transição: democracia e eleições no governo Collor. São Paulo: Loyola.

Lamounier, Bolivar e Raquel Meneguello (1986). Partidos políticos e consolidação democrática: o caso brasileiro. São Paulo: Brasiliense.

Lane, Robert (1962). Political Ideology. New York: Free Press.

e D. O. Sears (1967). A opinião pública. Rio de Janeiro: Zahar.

Lavareda, A. (1991). A democracia nas urnas: o processo partidário eleitoral brasileiro. Rio de Janeiro: Rio Fundo/Iuperj.

Lavrakas, P.J. e M. W. Traugott (2000). Election polls, the news media and democracy. New York: Chatham House.

Lazarsfeld, Paul et al. (1966). Voting: a study of opinion formation in a presidential campaign. Chicago: The University of Chicago Press. Press.

et al. (1965). The people's choice. New York/London, Columbia University

Leal, Victor Nunes (1949). Coronelismo, enxada e voto. Rio de Janeiro: Florense.

Lima Jr. e B. Olavo (1978). Articulação de interesses, posição sócio-econômica e Ideologia: as eleições de 1976 em Niterói. In: F. W. Reis (org.). Os partidos e o regime: a lógica do processo eleitoral brasileiro. São Paulo: Símbolo.

(1989). O voto ideológico na eleição de 1988 e na campanha presidencial. $\mathrm{Ca}$ dernos de Conjuntura. Rio de Janeiro: Iuperj, n. ${ }^{\circ} 22$.

(1990). As recentes eleições brasileiras: tendências e dilemas de interpretação. Sistema partidário e alternativas da oposição. Cadernos de Conjuntura. Rio de Janeiro: Iuperj, n. 27.

(1990). Alienação eleitoral e os seus determinantes - nota de pesquisa. Revista Brasileira de Ciências Sociais, n. $^{\text {o } 14 .}$

Lima, Venício A de. (1994). Televisão e poder: a hipótese do cenário de representação da política. In: $\mathrm{O}$ enredo eleitoral. Comunicação \& Política, n. ${ }^{\circ} 1$. Rio de Janeiro: Cebela.

(1994). Propaganda política no rádio e na televisão. In: Matos, Heloiza (org.). Mídia, eleições e democracia. São Paulo: Página Aberta.

Magalhães, Nara Maria Emanuelli (1998). O povo sabe votar: uma visão antropológi$c a$. Rio de Janeiro: Vozes.

Malhotra, Naresh (2001). Pesquisa de marketing: uma orientação aplicada. Porto Alegre: Bookman. 
Manin, Bernard (1995). As metamoforses do governo representativo. Revista Brasileira de Ciências Sociais, São Paulo, n. ${ }^{\circ} 29$.

Martinez-Alier, V. e A. Boito Jr. (1975). 1974: Enxada e voto. In: B. Lamounier e F. H. Cardoso. Os partidos e as eleições na Brasil. São Paulo: Paz e Terra.

Matos, Heloiza (org.) (1994). Mídia, eleições e democracia. São Paulo: Página Aberta.

McCombs, Maxwell e Donald L. Shaw (1972). The agenda-setting function of mass media. Public Opinion Quarterly, n. ${ }^{\circ} 36$.

Mendelsohn, H. (1972). Polls, television and new politics. Pennsylvania: Chandler Publishing Company.

Mendes, Antônio M. T. (1991). O papel das pesquisas eleitorais. São Paulo: Novos Estudos Cebrap, n. ${ }^{\circ} 29$.

Mendes, Antônio M. T. e Gustavo Venturi (1994). Eleição presidencial: o Plano Real na eleição de Itamar Franco. XVIII Encontro Anual da Anpocs, Caxambu: Mimeo.

Meneguello, R. (1994). Partidos e tendências de comportamento: o cenário político em 1994. In: E. Dagnino (org.). Os anos 90: política e sociedade no Brasil. São Paulo: Brasiliense.

(1998). Partidos e governos no Brasil contemporâneo. São Paulo: Paz e Terra.

Meneguello, Rachel, Mainwaring, Scott and Timoty Power (2000). Partidos Conservadores no Brasil Contemporâneo. Rio de Janeiro: Paz e Terra.

Meyer, Philip (1989). Precision journalism and 1988 US elections. International Journal of Public Research, v. 1, n. $^{\circ} 3$.

Miceli, Sergio (1991). O dia seguinte. In: Adauto Novaes (org.). Rede imaginária: televisão e democracia. São Paulo: Companhia das Letras.

Moisés, José Álvaro (1990). Eleições, participação e cultura política. Lua Nova, São Paulo, n. ${ }^{\circ}$ 22, Cedec.

(1995). Os brasileiros e a democracia: bases sócio-políticas da legitimidade democrática. São Paulo: Ática.

Muszynski, Maria Judith de Brito e Antônio Manuel Teixeira Mendes (1990). Democratização e opinião pública no Brasil. In: B. Lamounier (org.) De Geisel a Collor: o balanço da transição. São Paulo: Sumaré/Idesp/CNPq.

. (1989). Os eleitores paulistanos em 1986: a marca do oposicionismo. In: Maria Tereza Sadek (org.). Eleições/1986. São Paulo: Vértice/Idesp.

Neuman, W. Russell (1986). The paradox of mass politics: knowledge and opinion in the american electorate. Cambridge: Harvard University Press.

Novaes, Adauto (org.) (1991). Rede imaginária: televisão e democracia. São Paulo: Companhia das Letras.

Nunes, Márcia Cavallari, Örjan Olsén e Joseph Straubhaar (1993). O uso de pesquisas eleitorais em decisões de voto: as eleições brasileiras de 1989. Opinião pública, v. 1, n. ${ }^{\circ} 2$. 
Nunes, Márcia Cavallari (2000). O papel das pesquisas. In: R. Figueiredo (org.) Marketing político e persuasão eleitoral. São Paulo: Fundação Konrad Adenauer.

Palmeira, Moacir e Irlys Barreira (1998). Candidatos e candidaturas: enredos de campanha eleitoral no Brasil. São Paulo: Annablume Editora.

Porto, Mauro (1994). As eleições municipais em São Paulo. In: Heloiza Matos (org.). Mídia, eleições e democracia. São Paulo: Página Aberta.

(1995). Limites da racionalidade: as relações entre mídia e política. XIX Encontro Anual da Anpocs. Caxambu: Mimeo.

Pierucci, Antonio Flávio (1987). As bases da nova direita. Novos Estudos Cebrap, n. ${ }^{\circ}$ 19.

(1989). A direita mora no outro lado da cidade. Revista Brasileira de Ciências Sociais. Anpocs, n. ${ }^{\circ}$ 10, v. 4.

. e M. C. Lima (1991). A Direita Flutuante. Novos Estudos Cebrap, n. 29. n. ${ }^{\circ} 35$

e M. C. Lima (1993). São Paulo 92, a vitória da direita. Novos Estudos Cebrap, . (1999).Ciladas da diferença. São Paulo: Editora 34.

Pinto, Celi Regina Jardim (1993). O clientelismo eletrônico: a eficácia de um programa popular de rádio. Humanas, Revista do Ifch/Ufrgs, v.16, n. ${ }^{\circ} 1$.

. (1995). Ao eleitor a verdade: o discurso político da imprensa em tempos de eleições. In: M. Baquero. Transição, eleições e opinião pública. Porto Alegre: Ed. Universidade/Ufrgs.

Popkin, Samuel L. (1991). The reasoning voter: communication and persuasion in presidential campaigns. Chigaco/London: University of Chicago Press.

Reis, Fábio Wanderley (1975). As eleições em Minas Gerais. In: Bolivar Lamounier e Fernando Henrique Cardoso. Os partidos e as eleições no Brasil. Rio de Janeiro: Paz e Terra.

Reis, Fábio Wanderley (org.) (1978). Os partidos e o regime: a lógica do processo eleitoral brasileiro. São Paulo: Símbolo.

(1978). Classe social e opção partidária: as eleições de 1976 em Juiz de Fora. In: Reis, Fábio Wanderley (org.). Os partidos e o regime: a lógica do processo eleitoral brasileiro. São Paulo: Símbolo.

Rosembeg, Shawm e Patrick Mccafferty (1987). The image and the vote: manipulating voter's preferences. Public Opinion Quartely. Chicago: American Association for Public Opinion Reserch/University of Chicago, v. 51, n. ${ }^{\circ} 1$.

Rubim, Antônio Albino Canelas (1989). Comunicação, espaço público e eleições presidenciais. Comunicação \& Política, v. 9.

(1999). Mídia e política no Brasil. João Pessoa: Editora Universitária Ufpb.

(2000) (org.). Mídia e eleições 98. Salvador: Ed. Universitária Ufbp/Facom/Ufba. 
Sadek, Maria Tereza (org.) (1989). Eleições/1986. São Paulo: Vértice/Idesp.

Santos, Wanderley G. (1977). As eleições e a dinâmica do processo político brasileiro. Dados, n. ${ }^{\circ} 14$.

(1989). Eleições 1989. Cadernos de Conjuntura. Rio de Janeiro: Iuperj, n. 25.

Silveira, Flavio E. (1991). Pesquisas eleitorais e voto no Brasil. Revista de Ciências Humanas. Porto Alegre, n. 12.

(1994). Comportamento eleitoral em Porto Alegre nas eleições presidenciais 1994. Relatório de Pesquisa. Porto Alegre: Mimeo.

v. 2, n. $^{\circ} 2$.

(1994). Escolha intuitiva: nova modalidade de decisão do voto. Opinião pública,

(1998). A decisão do voto no Brasil. Porto Alegre: Edipucrs.

(1999). A decisão eleitoral: imagem, mídia e marketing. In: E. Pedroso (org.)

Eleições: história e estratégias. Porto Alegre: Evangraf.

(2000). A dimensão simbólica da escolha eleitoral. In: Figueiredo, R.(org.)

Marketing político e persuasão eleitoral. São Paulo: Fundação Konrad Adenauer.

(org.) (2002). Estratégia, mídia e voto. Porto Alegre: Edipucrs.

Simão, Aziz (1956). O voto operário em São Paulo. Revista Brasileira de Estudos Políticos Belo Horizonte, v. ${ }^{\circ} 1$, n. $^{\circ} 1$.

Singer, André (1990). Collor na periferia: a volta por cima do populismo. In: Lamounier Bolivar (org.). De Geisel a Collor: o balanço da transição. São Paulo: Sumaré/Idesp/CNPq. (2000). Esquerda e direita no eleitorado brasileiro. São Paulo: Edusp.

Soares, Gláucio (1964). Alianças e coligações eleitorais: notas para uma teoria. Revista Brasileira de Estudos Políticos. Belo Horizonte, n. ${ }^{\circ} 17$. n. ${ }^{\circ} 4$.

(1965). Bases ideológicas do lacerdismo. Revista Civilização Brasileira, ano 1, (1973). Sociedade política no Brasil. São Paulo: Difel.

Thiollent, Michel (1989). Pesquisas eleitorais em debate na imprensa. São Paulo: Cortez.

Trindade, Hélgio (1974). Os padrões de comportamento eleitoral no Rio Grande do Sul. Revista do Ifch da Ufrgs, v.1.

(1975). Anatomia do voto em Porto Alegre. Revista do Ifch da Ufrgs, v. 2.

(1975b). Padrões e tendências do comportamento eleitoral no Rio Grande do Sul (1950/1974). In: B. Lamounier e F. H. Cardoso (orgs.). Os partidos e as eleições no Brasil. Rio de Janeiro: Paz e Terra.

e J. de Cew (1978). Confrontação política e decisão eleitoral. In: F. W. Reis (org.) Os partidos e o regime. São Paulo: Símbolo. 
Vianna, Oliveira (1930). Problemas de política objetiva. São Paulo: Companhia Editora Nacional.

(1951). Instituições políticas brasileiras. Rio de Janeiro: José Olympio Editora.

Xausa, Leônidas e Francisco Ferraz (1967/8). As eleições de 1966 no Rio Grande do Sul. Revista Brasileira de Estudos Políticos. Belo Horizonte, n. ${ }^{\circ}$ 23-24.

Wolton, Dominique (1989). La communication politique: construction d'un modéle. Le Nouvel Espace Public. Editions du Centre national de la Recherche Scientifique. Paris, 1989. 